\title{
An Empirical Study on Postgraduate Education of Business English in China
}

\author{
Lu Xuemei ${ }^{1} \&$ Zhu Wenzhong ${ }^{2}$ \\ ${ }^{1}$ School of English for International Business, Guangdong University of Foreign Studies, Guangzhou, China \\ ${ }^{2}$ School of Business, Guangdong University of Foreign Studies, Guangzhou, China \\ Correspondence: Zhu Wenzhong, School of Business, Guangdong University of Foreign Studies, Guangzhou, \\ 510420, China. E-mail: 1129498654@qq.com
}

Received: July 4, 2019 Accepted: July 26, 2019 Online Published: August 9, 2019

doi:10.5539/hes.v9n4p1 URL: https://doi.org/10.5539/hes.v9n4p1

\begin{abstract}
The development of business English (BE) program cannot separate from that of its closely-related discipline. However, little is known about business English disciplinary development from the angle of postgraduate education in China. Through questionnaires and interviews on 64 postgraduate students of Guangdong University of Foreign Studies (hereinafter referred to as GDUFS), this paper conducts empirical research on and analysis of its postgraduate education from the perspectives of curriculum setting, teacher construction, and tutorial system. The results show that most respondents are content with these dimensions of the postgraduate education of business English, which demonstrates the current postgraduate education in GDUFS is highly recognized and satisfied. It aims to have implications for the reform and practice of postgraduate education and disciplinary construction in terms of business English in China. This research also discovers some noteworthy problems and puts forward some suggestions.
\end{abstract}

Keywords: business English, postgraduate education, discipline construction, empirical study, GDUFS

\section{Introduction}

With economic globalization deeper in recent years, business English program has gained unprecedented development opportunities. In the late 1960s, English for Specific Purposes (ESP) came into existence as a result of a Brave New World, a revolution in linguistics, and focus on the learner (Hutchinson \& Waters, 1987). ESP, an English related to a specific program, is characterized by specialized aim rather than special language (Mackay and Mountford, 1978). The purpose and content of ESP education are determined by learners' needs for functions and practical applications of English, rather than by the goal of general education (Strevens, 1988). ESP is often aimed at a certain occupational requirement or regulation, generally referring to English teaching for practical purposes (Mackay and Mountford, 1978). As a branch of ESP (Hutchinson \& Waters, 1987; Ellis \& Johnson, 1994), business English (BE) is a special discipline of applied linguistics, with the consequence of economic globalization and trade internationalization. Currently, business English is involving into an interdisciplinary subject covering language and business in China whose theoretical foundations are concerned with linguistics, intercultural communication, economics, management, education, computer science and so on (Zhu, 2008).

ESP was once regarded as a linguistic revolution, with the research centering on language application ways in the communicative environment rather than the formal features of language use (Hutchinson \& Waters, 1987). Business English is divided into English for General Business Purposes (EGBP) and English for Specific Business Purposes (ESBP). Business English, a new stage in the development of ESP, has gone through six basic stages of development. The first stage, from 1960s to 1970s, is called register analysis stage. Focusing on language at the sentence level, it is represented by Barber (1962) and Halliday (1964) who believe that any ESP must be in the register and language environment. Register includes field, tenor and mode (Hu et al., 2005). Discourse analysis comes second, starting from the early 1970s. During this period, ESP pays attention to linguistic rhetoric beyond the sentence, which is represented by Widdowson (1978). With the beginning of late 1970s, the third stage is known as the stage of target situation or needs analysis when Munby (1978) makes great contributions to its development. In this phase, ESP course makes an analysis of the learner's target environment, and links the language analysis with the learners' learning objective in a bid to meet the needs of different 
learners. Starting from the early 1980s, skills analysis represented by Grellet (1981) dominates the fourth stage when ESP shifts its focus from language surface level to a deeper one-the thinking process of language use. The fifth phase, which begins in the late 1980s, is overwhelmed by learning-centered approach, with Hutchinson and Waters (1987) as the representatives. They claim that learning is a process of coordination between learners and target situation. Participators need to have sufficient understanding of the process in language learning when teaching ESP. At this point, business English has entered the sixth stage of development in China, that is, business English has grown into a new and interdisciplinary subject and improved increasingly. Most scholars (Chen \& Wang, 2009; Ye, 2014, Zhong et al., 2015) agree that business English is an applied interdisciplinary subject dominated by applied linguistics and based on multidisciplinary knowledge, focusing on the development and improvement of the disciplinary system and related teaching models.

Since the approval of the business English undergraduate program in 2007, business English teaching has scaled up tremendously. By the end of May 2017, a total of 324 universities in China have established business English undergraduate program, and 583 vocational colleges have set up BE major. It is estimated that more colleges and universities will actively apply for offering business English program in the future. However, the status quo of business English discipline is not satisfying. Since it gets off the ground, it fails to form a relatively complete and logical business English system which conforms to the practice of discipline (Weng, 2014). There are various problems to be solved in terms of business English program building. For instance, we are faced with serious problems like teacher construction, teaching material building, etc. Discipline construction cannot separate from postgraduate education. They also complement each other for business English. At present, some universities in China like University of International Business and Economics, Guangdong University of Foreign Studies and Shanghai University of International Business and Economics are endeavoring to explore BE's discipline system, course design, teaching syllabus and teaching model, contributing greatly to discipline's improvement. Nevertheless, most relevant studies are limited to theoretical exploration, and empirical researches are deficient $(\mathrm{Hu}, 2015)$. Also, there is a scarcity of researches probing into discipline construction and postgraduate education of business English since a substantial body of studies are concerned with talent cultivation model for BE undergraduates (Ping, 2009; Wang et al., 2014), Curriculum System (Peng \& Zhu, 2011), BE pedagogy (Lei, 2006).

This paper aims to investigate the general situation of BE postgraduate education based on curriculum setting, teacher building and tutorial system in the context of GDUFS and put forward some suggestions for the development of business English postgraduate education. The study fulfils this purpose by introducing the basic situation of these items in GDUFS and providing a picture of the target group's satisfaction with them. As such, the research questions involve: 1) What's the satisfaction with the curriculum design for BE postgraduates in GDUFS and improvement for it? ; 2) What's the satisfaction with the teacher construction of business English Studies in GDUFS and improvement for it?; 3) What's the satisfaction with tutorial work for business English postgraduates in GDUFS and improvement for it?

\section{Empirical Research}

\subsection{Basic Situation}

In order to be adapted to the fast-developing society and to education globalization, Guangdong University of Foreign Studies founded the School of English for International Business (SEIB) in 2001, a teaching institution aiming to foster top talents in International Business. As a pioneer in adopting English as the instructive language, SEIB has developed a training model dedicated to acquisition of both academic knowledge and practical skills for the purpose of ability cultivation. Thanks to the success of such a model, SEIB has already gained a reputation for quality graduates. The school has been in the leading position in China in terms of talent training model and teaching reform by making full use of advantages with respect to talent, teaching and scientific research. In 2008, SEIB became the very first school in China approved by the Academic Degree Commission of the State Council to launch the MA degree program on Business English Studies (a class-two discipline) under the class-one discipline of Foreign Language and Literature. There are three orientations under this program: Business Language, Business Culture and Business English Teaching. Besides, it also offers an MA module oriented at Forensic Linguistics. In 2012, SEIB launched the PhD degree program on Business English Studies (a class-two discipline) under the class-one discipline of Foreign Language and Literature. Therefore, it has accomplished a complete system of programs covering all levels including BA, MA and PhD degrees. MA degree program on Business English Studies is designed to cultivate top-quality business professionals, who are supposed to be proficient in English, sensitive to cross-cultural communication, and well-adjusted to global competitions with their systematic business knowledge, broad international vision. The business English postgraduate education practice in GDUFS has been committed to cultivating communicative 
competence and comprehensive ability and thus has received good social repercussion. As such, this program is of great appeal for enrolling graduating students. In the meantime, due to graduates' expertise in their professional fields as well as their good command of English, they are well received by reputable employers for many years (Zhu, 2010).

\subsection{Research Object}

The research object is composed by postgraduate students at all levels in SEIB of GDUFS. There are several factors explaining the selection of these samples. Students in the first year just finished their undergraduate education or experienced the working environment, so the gap between their expectation and experience is most prominent. As students in the second year basically have completed the course during the postgraduate period, they have grasped a more comprehensive understanding of teaching quality and course design. Since students in the last year have experienced the whole business English teaching process and most of them are hunting or have hunted for jobs, they get a better view of the match between employers' requirements and students' know-how. As a result, the research object has a full coverage of postgraduate students in different years who ponder questions in a reasonable and objective manner.

\subsection{Research Objective}

This paper launches an investigation into the curriculum setting, teaching staff construction and tutorial system based on postgraduate students in SEIB of GDUFS. Furthermore, we also take their suggestions on BE postgraduate education into consideration. This research is aimed to understand students' learning needs through their feedback and make a preliminary assessment of the talent cultivation of business English postgraduates. It is also hoped that the current teaching problems can be found and figured out so as to better the postgraduate cultivation model for business English.

\subsection{Research Methods}

This survey adopted the online anonymous questionnaire through Sojump, a Chinese professional online questionnaire survey, evaluation and voting platform providing some powerful functions like online design questionnaire, data collection and data statistical analysis. The collected data was proved to be valid by a careful sifting and software's evaluation. Considering possible unsatisfactory results from impatience with a too long questionnaire or too many gap-filling questions, this questionnaire only consists of ten questions in four forms: single choice, multiple choice, matrix scale and open-ended question. The single-choice questions are put first, while the open-ended question is put last so that this questionnaire can be filled in a progressive way. As for the single-choice questions, we put the question about their grade first and others mainly deals with students' satisfaction degree with course design, teachers, tutorial system and postgraduate education work. One sample item includes, "What's your overall satisfaction with the current curriculum designed for BE postgraduates in GDUFS?". As students may not be very content with the above measurement items, nearly every single choice concerning satisfaction is particularly followed by a multiple-choice question. In so doing, we can further analyze the underlying reasons or listen to students' opinions. The multiple choice is made up of three parts: the improvements of curriculum setting and teaching construction as well as the existing problems of tutoring work. An example item is "What do you think can be improved for BE curriculum setting?". The matrix scale touches on the importance evaluation on core courses, political and ideological theory, second foreign language, courses related to linguistics and applied linguistics, business-related courses as well as courses concerned with business English studies. Moreover, an open-ended question involving the improvements for postgraduate education work in GDUFS is set up at the end of the questionnaire. Moreover, when the draft questionnaire was completed, we sent it to two professors and three classmates for their suggestions. Finally, the final questionnaire was given out to the sampled participants from January 2019 to the end of April 2019. Finally, 30 first-year master students, 23 second-year master students and 11 third-year master students in the School of English for International Business (SEIB) of GDUFS filled in the questionnaire.

\section{Empirical Analysis}

In view of the fact that the empirical research adopted questionnaire, we used SPSS 22.0 software for validity and reliability analysis after the questionnaire was collected. The Cronbach' $\alpha$ coefficient value was 0.895 , which indicates that the research data had good reliability. Also, the KOM value was 0.766 , which was between 0.7 and 0.8 , indicating that the questionnaire was valid.

\subsection{Curriculum Setting}

The current postgraduate curriculum is composed by $70 \%$ linguistics-related courses and $30 \%$ business-related courses. This can be explained by talent cultivation localization, cultivation objective and interdisciplinary 
feature in terms of business English program. As shown in the Figure 1, 40.63\% participants were satisfied with current course design in GDUFS. The general satisfaction degree accounted for $35.94 \%$. Only $1.56 \%$ responders were very content with the course setting. Besides, the proportion of dissatisfaction and strong dissatisfaction was $18.75 \%$ and $3.13 \%$ respectively. Despite the fact that most of participants were satisfied with the curriculum setting, there were also some problems in it.

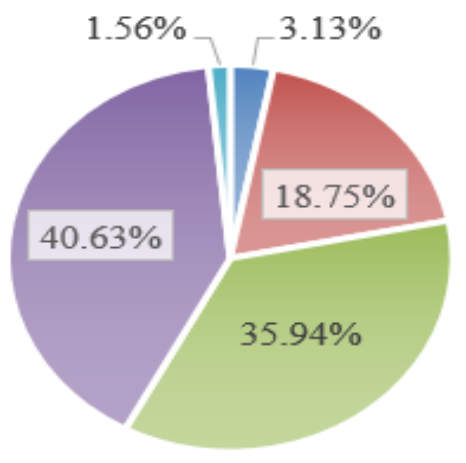

- Very unsatisfied

- unsatisfied

- Basically satisfied

- Satisfied

- Very satisfied

Figure 1. Degree of satisfaction with curriculum setting

An additional option concerning the improvements of current course design was specifically established for participants who were not very satisfied. According to the survey results, $90.48 \%$ of them believed that the practicality of courses needed to be enhanced. Of all the testees answering this question, $50.79 \%$ of them maintained that the courses were unreasonably offered in terms of term arrangement while $26.98 \%$ students thought that the courses were far from scientific (see the figure 2). In order to dig out the hidden cause, we had an in-depth interview with ten participants respectively after the questionnaire was collected. Only those who are not very satisfied with the curriculum setting had opportunity to answer the following question about improvements for course design, therefore, we randomly chose ten respondents who met the requirement and were willing to be interviewed at their spare time. The interviews were consented to be recorded and we made transcriptions according to the records later. Finally, courses were not of great value mainly due to the fact that there were too much linguistics-related courses compared with business-related ones. From the perspective of these students, they opined that the course arrangement was not very helpful to their future employment. Therefore, they proposed that an increasing number of practical courses would be added, which also derived from the strong desire of the third-year postgraduate students who were seeking jobs. In addition, some participants asserted that the time arrangement was somewhat unreasonable in that the first year's learning was focused on theoretical courses associated with linguistics while some important courses concerning analytical tools like corpus, statistics, etc, were offered in the second year. Such time design was not conducive to students' paper writing in the early stage. There were a number of students who complained that some courses were out of logic and coherence. For example, there was a lack of courses for paper writing guidance, with the result that some students met some basic writing format problems when completing the MA dissertation proposal.

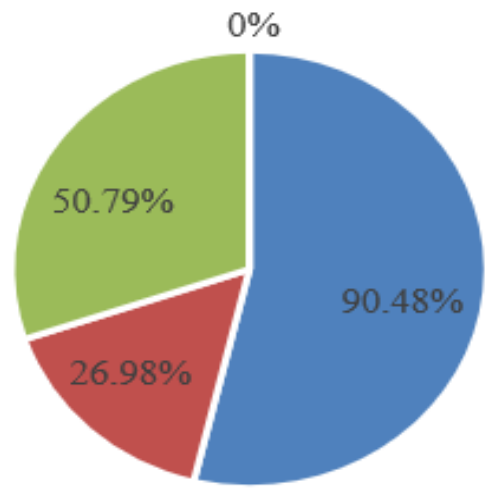

- Practical

- Scientific

- Reasonable

- Others (specify them)

Figure 2. Improvements for course design 
Currently, the major courses for students of Business English Studies offered by GDUFS include: 1) general courses: non-ideological and political theory, second foreign language; 2) linguistics-related courses: Systemic Functional Grammar, Pragmatics, Statistics, Theoretical Linguistics, etc; 3) business-related courses: Economics, Management, Accounting, International Business Studies, etc; 4) business English research courses: Theoretical Research of Business English, Teaching Business English Studies, Studies on Business Translation, etc. These four types of courses constitute the main body of business English postgraduate courses. Students are required to comprehensively use the theories and methods of the sub-disciplines of linguistics and business to systematically discuss the various characteristics and its application rules and social utility in terms of business language, business law language, business culture, and commerce under the constraints of a series of factors including business environment, business culture, business knowledge, and business subjects. Different from foreign linguistics and applied linguistics, business English discipline is characterized by business-related courses. Students are required to systematically master important theoretical knowledge in the fields of economy, management, and international trade so as to solve relevant language and communication problems through case analysis. The questionnaire also evaluated the importance of these kinds of courses using the Likert five-grade scale. Options 1-5 conveyed the following meanings: $1=$ not important, $2=$ less important, $3=$ generally important, 4 = important, 5 = very important. The results indicated that the students' evaluations of these five courses were quite different. The average value was between 2.75 and 4.55 . Of all major courses, the ideological and political theory course was thought to be the least important since they were not relevant to the program they chose. Participants regarded business relevant courses as most important, which also satisfied students' desire to open more business courses. Besides, these students claimed that linguistics courses were equally important but excessively offered (see Figure 3).

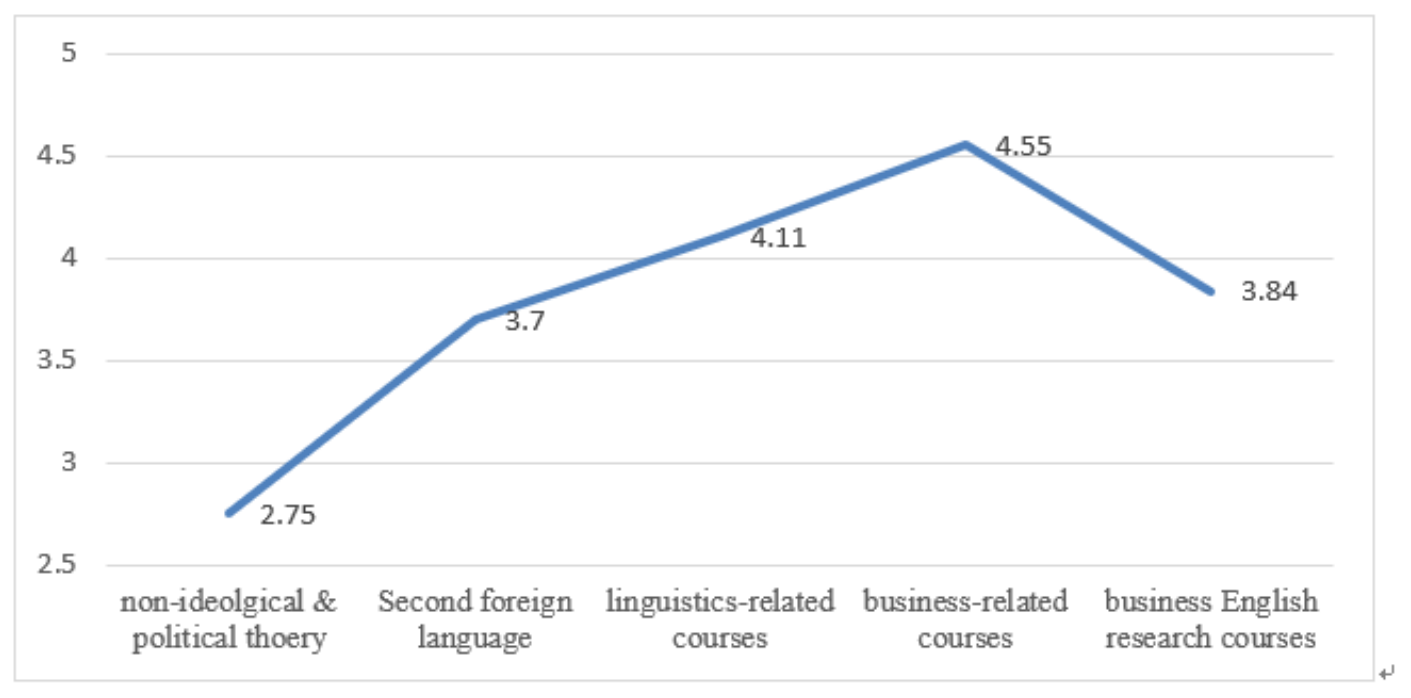

Figure 3. Importance evaluations of major courses

\subsection{Teacher Construction}

SEIB in GDUFS boasts a productive and experienced staff, $85 \%$ of whom have overseas educational background. All teachers have obtained at least master degree. In addition, SEIB has recruited many foreign experts experienced in either teaching or business practice, leading GDUFS in education internationalization. All these conditions, to a large extent, meet the need of English-instruction business English teaching and improve the quality of teaching. This questionnaire also investigates whether students are satisfied with business English teachers or not. It is found that there is a high degree of satisfaction towards the teachers. Put it simply, 59.38\% participants are satisfied with staff's teaching and those who take neutral attitudes account for $29.69 \%$. The proportion of strong satisfaction with teachers reaches $7.81 \%$ while $3.13 \%$ respondents are discontent. None of them are strongly dissatisfied with the teachers in SEIB (refer to Figure 4). 


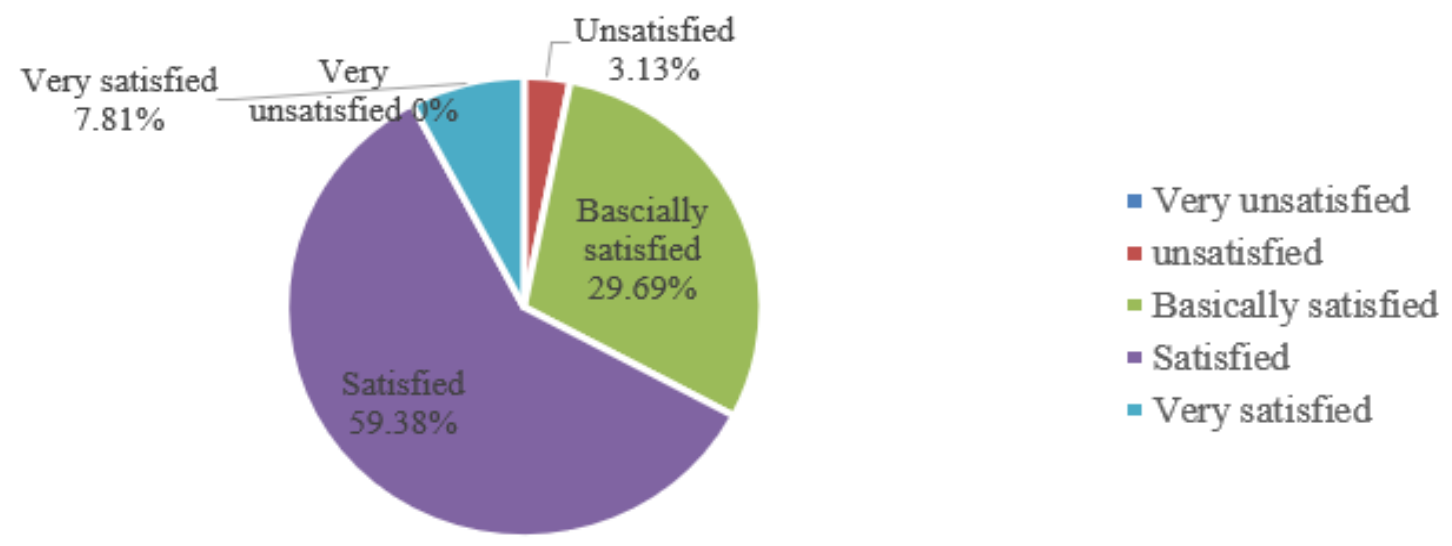

Figure 4. Students' satisfaction with business English teachers

In addition, we intended to make a further survey into students except those were fairly satisfied with the teachers so as to identify the underlying causes. Hence, the question of teachers' deficiencies in the eyes of students was take into account. The results indicated that $94.92 \%$ participants stated that the teaching approach remained to be improved. Following the same interview approach as curriculum setting, we had a deep conversation with ten of them. It was reported that some teachers delivered lessons as they liked while some took the form of mechanical teaching, which failed to allow for students' needs. Some interviewees believed that some lecturers adopted various teaching methods that were inconsistent with students' ability. $40.68 \%$ of responders claimed that there was room for improvement in teachers' professional knowledge while $15.25 \%$ of participants complained that some professors should enhance their language competence. We were also told that some teachers were supposed to better their moral character (refer to Figure 5).

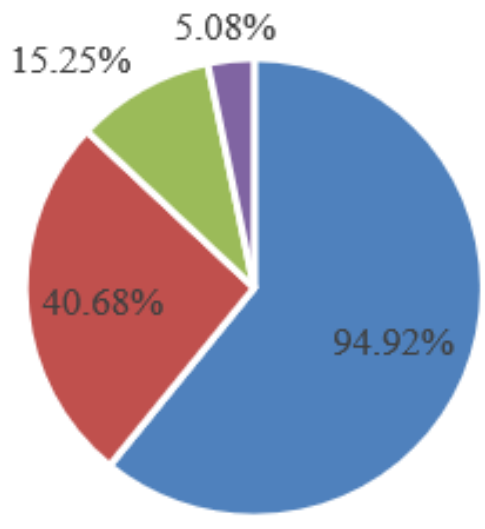

- teaching approach

- professional knowledge

- language competence

- Other

Figure 5. improvements for business English teachers

\subsection{Tutorial System}

According to the current tutorial system in SEIB of GDUFS, both students and tutors are entitled to select each other. Once the tutoring relationship is established, mentors should take such responsibility for their supervised students as ideological and political education, discipline guidance, research methods supervision and academic standards instruction. It stipulates that supervisors should have face-to-face conversation with students and pay attention to their academic problems which are to be addressed with the assistance of tutors. Meanwhile, tutors ought to give timely guidance to graduates' final dissertation involving topic selection, research scheme, time arrangement, expected goals until the students complete the dissertation writing. Noticeably, tutors are not responsible for students' successful defense for paper. 
By analyzing the questionnaire, we found that a majority of participants were satisfied with tutorial work. The students surveyed who were very satisfied, satisfied and basically satisfied accounted for $10.94 \%, 46.88 \%$ and $35.94 \%$ respectively. What's more, a few respondents were discontent with the current tutoring work (refer to Figure 6).

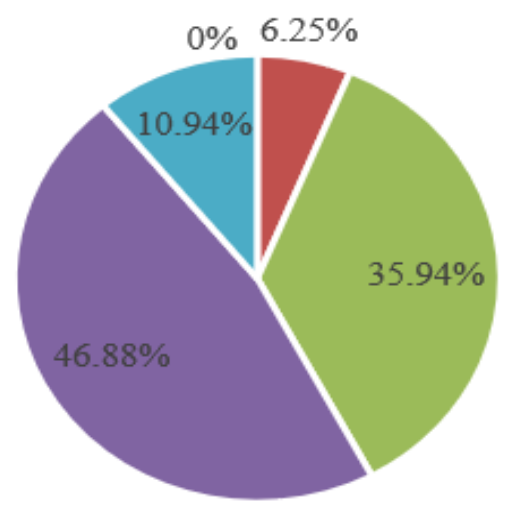

- Very unsatisfied

- unsatisfied

- Basically satisfied

- Satisfied

- Very satisfied

Figure 6. students' satisfaction with tutorial system

Through further investigation into the reason why the tutorial system was not very satisfactory, it was found that there existed some problems. 59.65\% of participants concluded that there was a lack of meetings and communication between students and mentors. 56.14\% of them were discontent because their supervisors provided too few academic programs in which students could participate while $52.63 \%$ responders attributed their dissatisfaction to the limited academic guidance that tutors offered, as a result of which their research ability was deficient. A small number of interviewees commented that there was generally a gap between the objective of students and that of tutors in that the former were career-driven while the latter academia-oriented, as is illustrated in Figure 7.

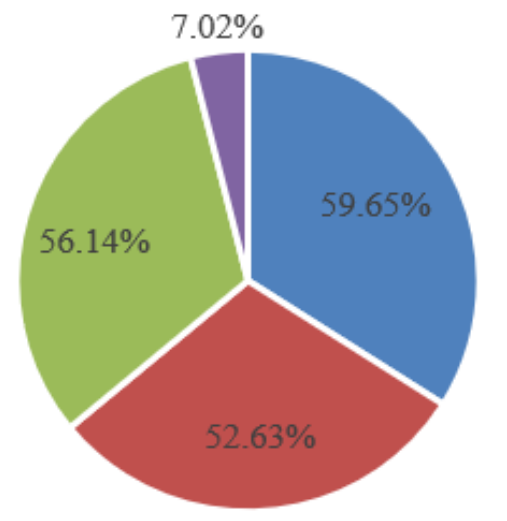

\author{
- limited meetings and \\ communication \\ - limited academic guidance \\ - limited program participation
}

- other

Figure 7. Problems in the tutorial work

The questionnaire also inquired into students' satisfaction with postgraduate education work of business English program. The results showed that the overall satisfaction degree was high. The proportion of great satisfaction, satisfaction and general satisfaction took $13 \%, 50 \%$ and 39.06\% respectively. Noticeably, not all participants were satisfied, but none of them were totally discontent (see figure 8). This demonstrated that postgraduate education model of business English in GDUFS received a higher recognition, greatly tallying with students' needs. 


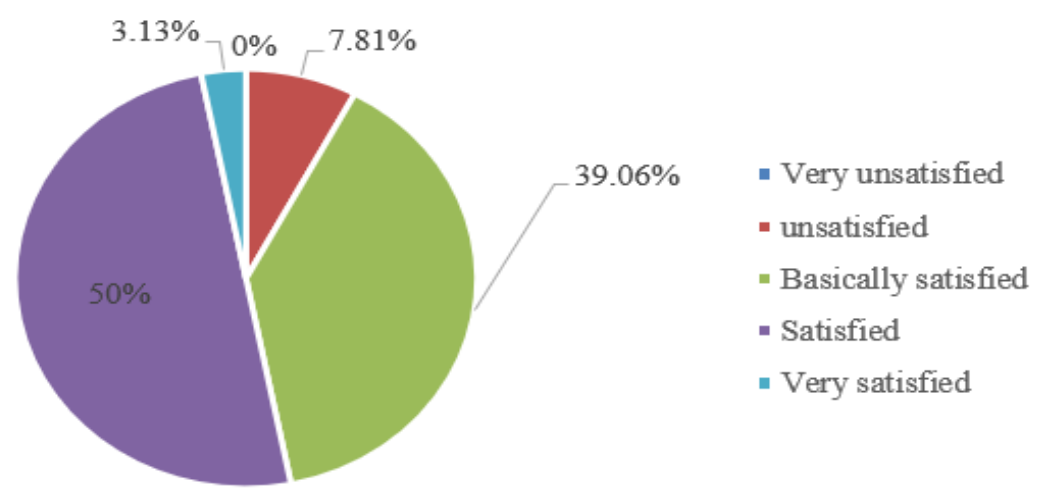

Figure 8. Students' satisfaction with postgraduate education work

Moreover, quite a few master-degree students presented some proposals for postgraduate education work in business English as well, which showed resemblance with the above-mentioned research questions. For instance, importance should be attached to strengthening dissertation writing and integrating theoretical knowledge with analytical tools teaching. It was hoped that more cooperative internship projects would be launched to keep students contacted with the outside community. Besides, the current tutorial system was expected to be improved and more useful resources would be available for students. In response with these feedbacks, this paper will put forward some suggestions.

\section{Conclusion}

Through the empirical investigation on and analysis of postgraduate education from the perspectives of curriculum setting, teacher construction and tutorial system, we obtain the following findings: Most participants are content with these dimensions. Moreover, the results indicate that there is a high degree of satisfaction in terms of the overall business English postgraduate work, which demonstrates that the current postgraduate work done in GDUFS is highly recognized and satisfied and the teaching model receives good effects, having positive implications for the reform and practice of postgraduate education in business English. The Postgraduate education work can be to some extent learned and promoted. The findings are mostly consistent with the prior research results that the teaching and management mode of business English in GDUFS wins higher recognition, and the business English graduates with proficient English would be more competitive in job-hunting (Zhu, 2010). Undeniably, there is room for improvement in terms of BE postgraduate education. For example, courses should be more practical and develop students' practical skills. The teaching approach remains to be improved, which affects students' interests in the course. Furthermore, there should be a reasonable mechanism that guarantees enough communication between students and their mentors. These improvement calls for the efforts of faculty, teachers, and students. As an important branch of ESP, business English has gradually developed into an independent discipline. The discipline development in business English needs the support from both undergraduate and postgraduate education, which contributes to the theoretical and practical research.

Nevertheless, some noteworthy problems are also discovered in terms of the postgraduate education work of business English. For example, the time arrangement for courses remains to be perfected. Courses for academic papers should be increased for the benefit of students' academic writing competency. In the light of the proportion of business-related courses and linguistics-pertinent ones, we offer a proposal that more frontier business lectures should be held for students in accordance with the disciplinary orientation of business English program. At the same time, students are also encouraged to audit or independently learn business-related courses in their spare time. As for the problems in teaching staff cultivation, we suggest that professors should appropriately listen to student's opinions and feedbacks in order to check out the problems affecting teaching results as well as improving and improving teaching approaches in a timely fashion. Furthermore, they are bound to consolidate professional knowledge and improve language expression competence. With regard to deficient communication between students and supervisors, we recommend that students should learn to self-study and actively communicate and discuss with the tutors on one hand. On the other hand, tutorial system is to be improved so that mentors can spare more time in helping students with learning and life struggle. This study is of practical significance for the reform and development of business English postgraduate education. However, the empirical research is only based on GDUFS. Thus, contrastive research and analysis would be made in the future. 


\section{References}

Barber, C. L. (1962). Some measurable characteristics of modern scientific prose. In F. Behre (Ed.), Contributions to English syntax and philology (pp.1-23). Stockholm, Sweden: Almqvist and Wiksell.

Chen, Z., \& Wang, L. (2009). On the Establishment of Business English BA Program in the Context of China's Latest Economic and Social Development. Foreign Languages in China, 6(4), 4-11+21.

Dudley-Evans, T., \& St. John, M. (1998). Developments in English for Specific Purposes: A Multi-disciplinary Approach. Cambridge: Cambridge University Press.

Ellis, M., \& Johnson, C. (1994). Teaching English. Oxford: Oxford University Press.

Grellet, F. (1881). Developing Reading Skills. Cambridge: Cambridge University Press.

Halliday, M. A. K., Angus, M., \& Peter, S. (1964). The Linguistic Sciences and Language Teaching. London: Longman.

Hu, W. Z. (2014). On the Cultivation of English Majors in China: Retrospect and Prospect. Foreign Language Teaching and Research, 1, 111-117.

Hu, Z. L., Zhu, Y. S., Zhang, D. L., \& Li, Z. Z. (2015). An Introduction to Systemic Functional Linguistics. Beijing: Peking University Press.

Hutchinson, T., \& Alan, W. (1987). English for Specific purpose. Cambridge: Cambridge University Press. https://doi.org/10.1017/CBO9780511733031

Lei, C. L. (2006). Content-based Instruction and Compound Foreign Language Teaching: Taking Teaching Model of Business English as an Example. Computer-assisted Foreign Language Education, 3, 32-38.

Lin, T. H. (2001). On the Development of Business English as a Discipline. Journal of Xiamen University, 4 , 3-15.

Mackay, R., \& Alan, M. (1978). English for Specific Purpose. London: Longman.

Munby, J. (1978). Communicative Syllabus Design. Cambridge: Cambridge University Press.

Ping, H. (2009). On the Talent Cultivation Model of Business English Undergraduates. Foreign Languages in China, 4, 18-21.

Strevens, P. (1998). ESP after twenty years: a re-appraisal. In M. Tickoo (Ed.) ESP: State of the Art (pp. 1-13). Singapore: SEAMEO Regional Language Centre.

Trimble, L. (1985). English for Science and Technology: A Discourse Approach. Cambridge: Cambridge University Press.

Wang, Y. Y., Wang, G. L., \& Zheng, L. N. (2014). Investigation on talent needs and cultivation pattern of business English majors and its implications. Foreign Language World, 2, 34-41.

Weng, F. (2014). On Dual-Track Development Mode of Business English. Journal of Foreign Language World, 2, 10-17.

Widdowson, H. G. (1978). Teaching Language as Communication. Oxford: Oxford University Press.

Ye, X. G. (2014). The Beginning, Evolution and Development Trend of Business English Teaching in China. Contemporary Foreign Languages Studies, 5, 1-6+76+79.

Zhong, W. H., Zhang, W. B., \& He, J. N. (2015). On Positioning BA in Business English Program in Higher Education. Foreign Languages in China, 12(1), 4-10.

Zhu, W. Z., \& Liao, F. (2008). On differences between general English teaching and business English teaching. English Language Teaching, 1(2), 90-95. http://dx.doi.org/10.5539/elt.v1n2p90

Zhu, W. Z. (2010). Business English Teaching Mode: Its Theoretical Evolution, Features and Performance. Journal of Guangdong University of Foreign Studies, 21(4), 22-27. 


\section{Appendix A}

\section{Questionnaire}

1. Which year are you in?

- first year

- Second year

- Third year

2. How are you satisfied with the current curriculum setting for BE postgraduates?

- Very satisfied

- Satisfied

- Basically satisfied

- Unsatisfied

- Very unsatisfied

3. What do you think can be improved for the current course design? (Multiple choice)

- Practical

- Scientific

- Reasonable

- Others (Please specify them)

4. Please rate the main courses for BE postgraduates according to their importance.

\begin{tabular}{|l|l|l|l|l|l|}
\hline & $\begin{array}{l}\text { not } \\
\text { important }\end{array}$ & $\begin{array}{l}\text { less } \\
\text { important }\end{array}$ & $\begin{array}{l}\text { generally } \\
\text { important }\end{array}$ & important & $\begin{array}{l}\text { very } \\
\text { important }\end{array}$ \\
\hline non-ideological and political theory & & & & & \\
\hline second foreign language & & & & & \\
\hline $\begin{array}{l}\text { linguistics-related courses (eg., Systemic } \\
\text { Functional Grammar, Pragmatics, Statistics, } \\
\text { Theoretical Linguistics, etc.) }\end{array}$ & & & & & \\
\hline $\begin{array}{l}\text { business-related courses (eg., Economics, } \\
\text { Management, Accounting, International } \\
\text { Business Studies, etc.) }\end{array}$ & & & & & \\
\hline $\begin{array}{l}\text { business English research courses (eg., } \\
\text { Theoretical Research of Business English, } \\
\text { Teaching Business English Studies, Studies } \\
\text { on Business Translation, etc.) }\end{array}$ & & & & & \\
\hline
\end{tabular}

5. How are you satisfied with your teachers?

- Very satisfied

- Satisfied

- Basically satisfied

- Unsatisfied

- Very unsatisfied

6. What do you think can be improved for the teachers?

- teaching approach

- professional knowledge

- language competence

- Other (Please specify them) 
7. How are you satisfied with the current tutorial system?

- Very satisfied

- Satisfied

- Basically satisfied

- Unsatisfied

- Very unsatisfied

8. What do you think can be improved for the tutorial system?

- More meetings and communication

- More participation in academic programs

- More academic guidance

- Other (Please specify them)

9. How are you satisfied with the current BE postgraduate education work?

- Very satisfied

- Satisfied

- Basically satisfied

- Unsatisfied

- Very unsatisfied

10. What do you think can be improved for the BE postgraduate education work?

(Notes: The Q3, Q6, and Q8 are invisible for participants who choose "very satisfied" in the Q2, Q5, and Q7.)

\section{Copyrights}

Copyright for this article is retained by the author(s), with first publication rights granted to the journal.

This is an open-access article distributed under the terms and conditions of the Creative Commons Attribution license (http://creativecommons.org/licenses/by/3.0/). 